\title{
A MUNKAMEMÓRIA-KAPACITÁS MÉRŐELJÁRÁSAI ÉS JELENTŐSÉGÜK A NEUROPSZICHOLÓGIAI DIAGNOSZTIKÁBAN
}

\author{
NÉMETH DEZSŐ-PLÉH CSABA
}

Szegedi Tudományegyetem, BTK, Pszichológia Tanszék, Szeged E-mail: nemethd@sol.cc.u-szeged.hu; pleh@edpsy.u-szeged.hu

\section{RACSMÁNY MIHÁLY}

Szegedi Tudományegyetem, BTK, Pszichológia Tanszék, Szeged University of Bristol, Department of Experimental Psychology

E-mail: racsmany@edpsy.u-szeged.hu

\section{KÓNYA ANIKÓ}

ELTE BTK Pszichológia Tanszék, Budapest

E-mail: konya@izabell.elte.hu

\begin{abstract}
A tanulmány célja a rövid távú emlékezeti rendszerek méröeljárásainak és ezek neuropszichológiai alkalmazhatóságának bemutatása. Számos neuropszichológiai kórkép hátterében megtalálható a munkamemória valamely alrendszerének károsodása, éppen ezért a méröeljárások diagnosztikai jelentöséggel bírnak. A tanulmány kiemelten foglalkozik Daneman és Carpenter „olvasásterjedelmi” eljárásának bemutatásával, amelynek magyar változatával az elmúlt években számos kutatást végeztünk. Részletesen fogunk szólni a munkamemória verbális információkért felelös alrendszerének széles körben használt méröeljárásáról, a „nemszó-ismétlési” tesztről, amelyről az utóbbi évek kutatásai kimutatták, hogy jól használható az SLI (Specific Language Impairment) kórkép diagnosztizálásánál. A tanulmány a neuropszichológiai vonatkozásokon felül megpróbálja felvázolni a különbözö tesztek és a munkamemória alrendszereinek kapcsolatát, a validitási problémákat, valamint bemutatja mind a hazai, mind a külföldi kutatási eredményeket
\end{abstract}

Kulcsszavak: $\quad$ munkamemória-kapacitás, nyelvelsajátítás, idegrendszeri lokalizáció, neuropszichológiai diagnózis 


\section{BEVEZETŐ}

A munkamemória kutatása kiemelkedő példája a kognitív neuropszichológiai szemléletnek, vagyis a kísérleti pszichológiai módszerek, modellek és a neuropszichológiai megfigyelések, esetleírások ötvözésének. A munkamemória-modell az elmúlt két évtizedben többször is megújult a neuropszichológiai bizonyítékok hatására, a rövid távú emlékezet neuropszichológiai diagnózisa pedig jó néhány, addig csak a laboratóriumokban használt módszerrel gazdagodott. Napjainkban a rövid távú emlékezeti zavarok diagnosztizálásánál, valamint a sérülés rehabilitációjánál megkerülhetetlen a munkamemória alrendszereinek és ezek kölcsönhatásainak beható ismerete. Tanulmányunkban egyszerre próbáljuk meg vázlatosan bemutatni a neuropszichológiai vizsgálatok elméleti hátterét képező munkamemória-modellt (BADDELEY, 2000) és azokat a széles körben használt vizsgálóeljárásokat, amelyek segítséget nyújthatnak a rövid távú emlékezeti sérülések helyes kezeléséhez.

\section{A MUNKAMEMÓRIA-MODELL}

A hatvanas, hetvenes években a rövid távú memóriát viszonylag egységes és paszszív rendszerként írták le, mely „előszobája” a hosszú idejű tárnak (ATKINSON, SCHIFFrin, 1968; MURDOCK, 1974). BADDELEY és Hitch (1974) számos kísérleti adatra hivatkozva elvetette az egységes memória hipotézist, és többkomponensü, dinamikus rendszert tételezett fel.

A modell a munkamemóriát olyan korlátozott kapacitású rendszerként írja le, amely hozzáférést biztosít a tudat számára az eltérő reprezentációkhoz, fenntartja és manipulálja az információt a kognitív feladathelyzetekben - mint például következtetés, tanulás, nyelvi megértés, képzelet, problémamegoldás -, és független információkat hoz interakcióba (BADDELEY, 2000).

Az egységes rövid távú rendszer koncepciójának feladása szükségessé tette több munkamemória-rendszer feltételezését. Az eredeti elmélet egy központi végrehajtó rendszert és két modalitásspecifikus alrendszert tételez fel: (1) fonológiai hurok (eredetileg artikulációs hurok), (2) téri-vizuális vázlattömb és a központi végrehajtó rendszer (magyarul áttekintést ad RACSMÁNY, 2000).

\section{Központi végrehajtó}

A központi végrehajtó olyan korlátozott kapacitású, modalitásfüggetlen rendszer, amelyet fokozottan használunk, amikor a megismerő rendszert jobban terhelő feladattal kerülünk szembe. Ez a rendszer összeköttetést teremt a téri-vizuális vázlattömb, a fonológiai hurok, illetve a hosszú távú emlékezeti rendszer között, valamint modulálja a két munkamemória-alrendszer működését. (A központi végrehajtó fogalma körüli problémákról lásd a PARKIN [1998] vs. BADDELEY [1998] vitát, valamint a végrehajtó funkció kutatását a jelen kötetben bemutatja RACSMÁNY és SZENDI tanulmánya a 417-433. [47-63.] oldalon.) 


\section{Téri-vizuális vázlattömb}

A téri-vizuális vázlattömb az eredeti modellben a téri-vizuális ingerek megtartásáért és manipulálásáért felelős alrendszer. Valószínűsíthető, hogy nem egységes rendszer, hanem létezik egy önálló téri és egy önálló vizuális munkamemória (BADDELEY, LOGIE, 1999).

\section{Fonológiai hurok}

A fonológiai hurok BADDELEY (1998) modellje szerint olyan alrendszer, amely beszéd alapú formában tárolja az információt és csak kis mértékben terheli a központi végrehajtót.

E rendszer működését demonstráló alapjelenségek: a fonológiai hasonlósági hatás, a szóhosszúsági hatás és az artikulációs elnyomási hatás. A fonológiai hasonlósági hatásra jó példa, hogy a fonológiailag hasonló mássalhangzókból álló listánál gyengébb a rövid távú emlékezeti teljesítmény. Az artikulációs elnyomás (vagy artikulációs elfedés) technikáját alkalmazva kimutatható, hogy nincs fonológiai hasonlósági hatás, ha a megjegyzéssel egy időben hangos artikulációt kell végezni. Ezzel a technikával a szubvokalizációt lehet megakadályozni. Az artikulációs elnyomás lerontja a szóhosszúsági hatást is, mely utóbbi azt jelenti, hogy gyengébb a felidézési teljesítmény szólistatanulásnál, ha a lista hosszabb szavakból áll. Markáns és sokat idézett példa erre, hogy a walesi gyermekek számterjedelme kisebb, mint angol anyanyelvű társaiké, aminek oka az lehet, hogy a walesi számnevek hoszszabb artikulációt igényelnek, mint az angol számnevek (ELLIS, HeNNELEY, 1980).

A fonológiai hurok a módosított munkamemória-elméletben kétkomponensủ rendszer, amely egy fonológiai tárból és egy artikulációs hurokból áll. A fonológiai tár, melyet Baddeley és munkatársai „belső fülnek” neveztek, 2-3 másodpercig tartja fenn a hallott anyagot. Az artikulációs hurok („belső hang”) a tárban lévő anyagot ismételgetés révén frissíti, lehetővé téve a relatíve hosszabb ideig történő megtartást. A vizuálisan bemutatott ingerek - például olvasás során - az artikulációs hurkon keresztül jutnak a tárba. Ezért figyelhető meg az a jelenség, hogy ha a célingereket vizuálisan mutatják be, akkor az artikulációs elnyomás hatására leromlik az emlékezeti teljesítmény, ugyanakkor párhuzamosan adott, nem figyelt beszéd esetén nincs romlás. Az artikulációs frissítéssel kapcsolatban figyelemre méltó eredmény, hogy súlyosan anartriás és dizartriás személyeknél, akiknél a beszéd sem vokálisan, sem szubvokálisan nem lehetséges, van szóhosszúsági hatás, ami a fonológiai hurok működését mutatja (GATHERCOLE, Hitch, 1993). A rövid távú emlékezeti feladatokban hétéves kor körül bekövetkező ugrásszerű javulás szintén az ismételgetéses komponenshez köthető (GATHERCOLE, 1999).

Amikor fonológiai hurokról vagy rövid távú memóriáról beszélünk, nem szabad megfeledkezni a hosszú távú emlékezet hatásáról sem. Közhelynek számít, hogy értelmes szavakból álló lista megjegyzése lényegesen könnyebb, mint az értelmetlen szavakból álló listáé. E lexikalizációs hatáson túl kimutatható az is, hogy azok a feladatok, amelyekben olyan értelmetlen szavakból álló listát kell megje- 
gyezni, amelyek az anyanyelv fonológiai mintázatába illeszkednek (például serkápanta), könnyebbek, mint amelyek hangzásban is eltérnek a nyelv rendszerétől (például strömpf). Azt a folyamatot, mikor a hiányos fonológiai anyagot rekonstruáljuk a már korábban tárolt anyagok (tudás), illetve a nyelv lexikai, szemantikai vagy fonológiai tulajdonságai segítségével, redintegrációnak nevezzük. Ez a rekonstrukciós folyamat az emlékezet tárolási és előhívási szakaszában fordulhat elő (GATHERCOLE, 1999).

\section{A NEMSZÓISMÉTLÉSI-FELADAT}

A fonológiai hurok legismertebb mérőeljárásai: a számterjedelem (digit-span), a szóterjedelem (word span) és a nemszóismétlési-feladat (non-word repetition). Az első két feladat során a személynek különböző hosszúságú szám-, illetve szólistát kell megtartania. Az a hátránya ezeknek a feladatoknak, hogy a redintegrációs folyamatok miatt nem tiszta mérőeljárásai a fonógiai huroknak. A nemszóismétlési-feladatnál a személynek az a feladata, hogy egyre hosszabb, értelmetlen szavakat hallás után ismételjen meg. A nem-szavak megegyeznek a vizsgálati személy anyanyelvének fonológiai struktúrájával. Az azonnali (1 mp-en belüli) viszszamondás miatt artikulációs frissítés, ismételgetés nem történik, ezért ez a teszt elsősorban a fonológiai tárat terheli. A redintegrációs folyamatok csak fonológiai szinten hatnak, ezért a nemszóismétlési-teszt a fonológiai hurok egyik legtisztább mérőeljárása. A kritikája a tesztnek, hogy mindenképpen vokalizációt kíván, tehát a hibázás produkciós eredetű is lehet, miközben a fonológia tár ép.

1. táblázat. A nemszóismétlési-teszt néhány angol és magyar nyelvű példája (GATHERCOLE, WiLlis, BADDELEY, EMSLIE, 1994 alapján; a magyar változatot Lukács Ágnes, Kónya Anikó és Racsmány Mihály készítette.)

\begin{tabular}{|l|l|l|}
\cline { 2 - 3 } \multicolumn{1}{c|}{} & \multicolumn{1}{c|}{ Angol értelmetlen szavak } & \multicolumn{1}{c|}{ Magyar értelmetlen szavak } \\
\hline 2 szótagú & Diller, Pennel & Zomás, Galonc \\
3 szótagú & Barrazon, Frescovent & Cselika, Vazóga \\
4 szótagú & Loddenapish, Pennerriful & Serkápanta, Berszidelén \\
5 szótagú & Altupatory, Reutterpation & Gyilonitora, Fortiklempelesz \\
\hline
\end{tabular}

\section{FONOLÓGIAI HUROK ÉS NYELVTANULÁS}

Az utóbbi idők kutatásának eredményei világítottak rá arra, hogy a fonológiai huroknak jelentős szerepe van a nyelvelsajátításban és a másodiknyelv-tanulásban (BADDELEY, GATHERCOLE, PAPAGNO, 1998). Szoros kapcsolat mutatható ki a szótár vagy szókincs növekedése és a fonológiai hurok kapacitása között. Longitudinális vizsgálatok bizonyítják, hogy a korábbi életkorban megfigyelt fonológiai hurok kapacitásbeli különbségei jól bejósolják a későbbi szókincsnövekedést. A nemszó- 
ismétlési-teszt korrelál legjobban a szótárral, még abban az esetben is, ha az elemzések folyamán parciális korrelációs statisztikai elemzéssel az IQ hatását kiküszöböljük. Számos bizonyíték van arra, hogy a fonológiai hurok jelentős szerepet játszik az új szavak tanulásában. Egy kísérletben gyermekeknek játékállatok nevét kellett megtanulniuk: ezek vagy újszerűek voltak, vagy ismerősek. Az első esetben a nagy fonológiai kapacitású gyermekek jobban teljesítettek, mint a kis kapacitásúak, míg ismerős nevek estén nem volt különbség a kis és a nagy kapacitású csoport között. Egy másik kísérletben szó-nemszó-párok tanulásakor a nagy fonológiai hurok kapacitású gyermekek jobban teljesítettek, mint a kisebb kapacitású társaik, míg szó-szó tanulási helyzetben itt sem volt különbség a két csoport között. SERVICE (1992) longitudinális vizsgálatban mutatta ki, hogy a nemszóismétlési-teszttel és számterjedelem feladattal mért 9-10 éves kori fonológia hurok kapacitás jó predikátora a 2 évvel később mért második nyelvi teljesítménynek. Egy másik vizsgálatban poliglott (legalább 3 nyelven beszélő) és nem poliglott személynek mérték meg az IQ-ját, téri-vizuális rövid távú emlékezeti és verbális munkamemória-feladatokban nyújtott teljesítményét. A két csoport között a számterjedelem és nemszóismétlési-tesztben volt különbség a többnyelvűek javára. A fenti eredmények arra utalnak, hogy a fonológiai hurok, azon belül is a fonológiai tár nyelvtanuló „készülék” (BADDELEY, GATHERCOLE, PAPAGNO, 1998).

\section{RANSCHBURG-EFFEKTUS ÉS A FONOLÓGIAI HUROK}

Annak, hogy elméletileg összekapcsoljuk a fonológiai hurok mérésére kidolgozott nemszó-tesztet a Ranschburg-effektussal, a hasonlósági hatás az alapja, amely mindkét elméleti megközelítésben hangsúlyt kap. A fonológiai hurok hasonlósági hatása a munkamemória-modell keretében empirikusan bizonyított módon az időleges megtartás ellen hat. Ranshburg Pál egy évszázaddal korábbi véleményét idézzük meg DAMÓ Eszter (2000) szakdolgozati munkája alapján. Ranschburg Pál szerint a hasonlósági zavar abból a közös okból eredeztethető, hogy a felfogás az egyidejü heterogén ingereknél nehezebb, mint a homogén ingereknél; annak okán, hogy az egyidejűleg megjelenő homogén ingerek egybeolvadnak, s így gátolják egymást. Magyarázatot ad ez arra, hogy a heterogén tudattartalmakra (a homogénnel szemben) nagyobb az emlékezeti terjedelem, valamint hogy az ismétlés is csak a heterogén tételeknél növeli a teljesítményt. Míg a homogén listánál, a fenti gondolatmenetben, még inkább egyneművé válik az anyag. Így például az általa használt szópár módszernél - az értelmetlen hárombetűs homogén szótagoknál csak a középső mássalhangzó cserélődik - a hasonlóság a tételpárokból álló sorozatok elemeinek azonosságából fakad (RANSCHBURG, 1902; CZIGLER, 1988).

Damó Eszter óvodás nagycsoportos gyerekeknél vizsgálta a hasonlóság szerepét, amelynek során többek között a nemszó-teszt és a szópár-teszt eredményeit is egybevetette. A nemszó-feladatban kapott hibázások száma tendenciaszerủen együtt jár a Ranschburg-féle homogén sor hibaszámával; hasonló együttjárás a könnyebb, heterogén soroknál nem volt látható. Ennél erőteljesebb a Meixner- 
féle szókincspróbával vizsgált aktív szókincs és a heterogén szópárok együttjárása. Az utóbbi felidézi bennünk azt a jelen tanulmányban korábban említett eredményt, amely a szókincs és a nemszó-teszt között fennáll. Habár ez most az eredmények elméleti összekapcsolása csupán, mégis érdekesnek tartjuk feltételezni, hogy a Ranschburg-féle homogén effektus hátterében a fonológiai hurok is ott áll.

\section{FONOLÓGIAI HUROK ÉS SLI}

Az SLI (Specific Language Impairment) vagy magyarul specifikus nyelvi károsodás olyan kognitív fejlődési rendellenesség, amelyre a nyelvi deficit a jellemző, miközben az egyéb képességek normális fejlődést mutatnak. Hallási, kognitív vagy neurológiai károsodás nem mutatható ki e diagnosztikus kategória definíciója szerint. Ezek a gyerekek relatíve későn kezdenek el beszélni, és akkor is alacsonyabb nyelvi szinten, és kevesebb kifejezés produkálnak, mint koruk vagy intelligenciájuk alapján várható lenne. Károsodás mutatható ki a nyelv fonológiai, morfológiai és szintaktikai aspektusaiban is (JOANISSE, SEIDENBERG, 1998).

Fonológia - SLI-s gyermeknek komoly problémái vannak olyan szavak kimondásakor, amelyeknél mássalhangzó-torlódás fordul elő, de nehézségekbe ütközik a szavak fonológiai szerkezetének elemzése is. Nem tudják azonosítani ugyanazon kezdő fonémával kezdődő szavakat; például hogy a bank és a beteg szavak első hangja megegyezik. Normál személyeknél rosszabbul teljesítenek akkor is, amikor a hallott beszédben detektálni, kategorizálni kell egy fonémát (például a $t$-t). Értelmetlen szavak ismétlésében is rosszabbul teljesítenek.

Morfológia - Az affixumok és összetett szavak képzése is normál szint alatti. Angol anyanyelvủ SLI-s gyermekek - különösen új szavaknál - rosszul teljesítenek a múlt idő és a többes szám képzésében. Jó példa erre a wug-teszt, mely során jelentés nélküli szavaknak kell többes számát képezni (például wug, blick). E tesztnél a korosztályuknál rosszabbul teljesítenek az SLI-s gyermekek.

Szintaxis - Összetett és szenvedő mondatok elemzése szintén nehezen megy ezeknek a gyerekeknek.

Az SLI-t magyarázó elméletek nagyjából két csoportra oszthatók. Az egyik nézet (PINKER, 1999) magasabb szintű nyelvi károsodást vél a jelenségek hátterében. Innátista, moduláris megközelítésről van szó, amely a nyelvi modul specifikus sérülését hangsúlyozza. A másik megközelítés a nyelvtan károsodása helyett az alacsonyabb szintű, illetve feldolgozási folyamatok szerepét tanulmányozza (JOANISSE, SEIDENBERG, 1998). E nézet összhangban van KARMILOFF-SMITH (1998) neurokonstruktivista szemléletével, mely a merev moduláris elméletek helyett a modularizáció fejlődési folyamataira helyezi a hangsúlyt, és a rendellenességek okait alacsonyabb szinten kutatja, mint a károsodott kognitív modulok. A neurokonstruktivista szemlélet a minél fiatalabb korban kezdődő longitudinális kutatásokat preferálja. Így a fejlődési folyamatról pontosabb képet kapunk, mely könnyebbé teheti a kognitív károsodások megértését. 
JOANISSE és SEIDENBERG (1998) az SLI hátterében fonológiai szintủ folyamatokat tételez fel. Véleményük szerint a nyelv különböző aspektusainak károsodása is összekapcsolható ezen a szinten. A fonológiai munkamemória korlátozott kapacitása vethető fel az SLI magyarázataként. Ezt a hipotézist támasztják alá a fonológiai hurokkal kapcsolatos vizsgálatok is (BADDELEY, GATHERCOLE, PAPAGNO, 1998). SLI-s gyermekeknél a fonológiailag új szavak tanulása a kontrollhoz képest gyenge, míg ismert szavak esetén a teljesítmény a két csoport között megegyezik. Ez az eredmény akkor is igaz, ha a kontrollt egészséges, de nyelvileg egy szintű csoportok alkotják. Nemszóismétlés-tesztnél is az SLI csoport teljesítménye lényegesen alacsonyabb, mint az egészséges kontrollcsoporté.

Ezek az eredmények azt mutatják, hogy a specifikus nyelvi károsodás hátterében fonológiai hurok deficitje áll. A nemszóismétlés-teszten mutatott teljesítmények alapján a fonológiaihurok-tár komponense felelős az SLI tüneteiért. A nemszó-teszt mindezeket figyelembe véve diagnosztikus jelentőségủ e tünetcsoportnál.

\section{OLVASÁSI TERJEDELEM TESZT}

Míg a nemszó-teszt a fonológiai hurok egyéni különbségeinek mérőeljárása, addig az olvasási terjedelmi tesztet (reading span) általános verbális munkamemóriakapacitás mérésére dolgozta ki DANEMAN és CARPENTER (1980). A vizsgálati személynek ebben a helyzetben mondatokat kell hangosan olvasnia és meg kell jegyeznie a mondatok utolsó szavát, s természetesen meg kell értenie a mondatot is. A szerzők szerint ez azért munkamemória-mérő eljárás, mert nemcsak meg kell tartani az információt (tárolási komponens), hanem közben aktív műveleteket is kell végezni (például kiválasztani az utolsó szót, hangos olvasás, aktív megértés stb.). A teszt alkotói szoros kapcsolatot találtak a szövegmegértési teljesítmény, az olvasási képességek és az olvasási terjedelem feladattal mért munkamemóriakapacitás között. Az évekkel később JUST és CARPENTER (1992, 1996) által kidolgozott kapacitáselmélet szerint a nyelvi teljesítmények egyéni különbségeinek hátterében az eltérő munkamemória-kapacitás áll, amely egy egységes korlátozott kapacitású rendszer. Nyelvi teljesítményen már nemcsak a szövegmegértési feladatokat, hanem az on-line és off-line módszerekkel mért mondatmegértési feladatokat értik. Az elmélet lényege az, hogy azok a személyek, akiknek az olvasási terjedelem feladattal mért munkamemória-kapacitásuk nagyobb, jobban teljesítenek összetett mondatok, lexikailag kétértelmü mondatok, garden-path mondatok (szintaktikailag időlegesen kétértelmű mondatok) megértésében, továbbá külső emlékezeti terhelésnél, és összefüggő szövegmegértési feladatokban. A megértés ezekben a kísérletekben két tényezőt jelent: (1) az ingerbemutatás utáni megértést ellenőrző kérdések (off-line módszer) megválaszolását és (2) a megértést közvetlen, azonos időben (mondat közben) mérő eljárásokat (on-line módszerek). Az (1) off-line módszerre példa, amikor a kísérletvezető a következő garden-path mondat után - „A kutyám széttépte macska fehér volt” - azt a kérdést teszi fel, hogy: „Melyik állat tépte szét a másikat?” Gyerekekkel történő kísérleteknél játékállato- 
kon kell bemutatnia a vizsgálati személynek a mondat értelmét. Az on-line módszerekre példa ezekben a kísérletekben az olvasás alatti szemmozgás-regisztráció, illetve az önütemezett olvasási helyzet, amelyeknél pontosan mérhető a szavankénti feldolgozási idő.

A kapacitáselmélet (CARPENTER, MIYAKE, JUST, 1994) az olyan nyelvi zavarok, mint az afázia vagy dyslexia esetében is a korlátozott műveleti és tárolási kapacitású munkamemória-rendszer működését teszi felelőssé.

2. táblázat. Az olvasási terjedelem teszt mondatainak néhány magyar nyelvủ példája

(A mondatokat Racsmány Mihály és Németh Dezső készítette)

\begin{tabular}{|c|c|c|}
\hline & Mondatok & Felidézendő szavak \\
\hline $\begin{array}{l}2 \\
\text { szavas } \\
\text { sorozat }\end{array}$ & $\begin{array}{l}\text { Az olaj kiömlött, a könyv pedig azon nyomban meg- } \\
\text { gyulladt és már lángolt is, mint a száraz rőzse. } \\
\text { Ahogy vállunkon a hátizsákkal felfelé ballagtunk az } \\
\text { ösvényen, szép lassan beköszöntött az este. }\end{array}$ & $\begin{array}{l}\text { Rőzse } \\
\text { Este }\end{array}$ \\
\hline $\begin{array}{l}3 \\
\text { szavas } \\
\text { sorozat }\end{array}$ & $\begin{array}{l}\text { Hiába várták egész nap kétségbeesetten a fontos üze- } \\
\text { netet, csak másnap délután szólalt meg a csengő. } \\
\text { A ruhásszekrény hirtelen felborult és hatalmas ro- } \\
\text { bajjal tört darabokra az oldalára szerelt régi tükör. } \\
\text { Reggel a szerzetes furcsa arcot vágott, mikor ráesz- } \\
\text { mélt, hogy a toronyból hiányzik az új harang. }\end{array}$ & $\begin{array}{l}\text { Csengő } \\
\text { Tükör } \\
\text { Harang }\end{array}$ \\
\hline $\begin{array}{l}4 \\
\text { szavas } \\
\text { sorozat }\end{array}$ & $\begin{array}{l}\text { A betörő óvatosan a sötét szobába lépett, és a szíve is } \\
\text { megállt ijedtében, mikor felgyulladt a lámpa. } \\
\text { A sok éhes ragadozó és a betegségek miatt néhány év } \\
\text { alatt teljesen elnéptelenedett a bájos sziget. } \\
\text { Szinte mindenki adakozott az egyháznak, hogy végre } \\
\text { felépüljön a főtéren a várva várt új torony. } \\
\text { A vezetőség egy teljes héten át vitatkozott, mégsem } \\
\text { tudták eldönteni, hogy ki legyen az új elnök. }\end{array}$ & $\begin{array}{l}\text { Lámpa } \\
\text { Sziget } \\
\text { Torony } \\
\text { Elnök }\end{array}$ \\
\hline
\end{tabular}

Számos kutatás kétségbe vonja a fenti eredmények érvényességét, és az egykomponensű általános munkamemória-hipotézist (CAPLAN, WATERS, 1999; WATERS, CAPLAN, 1996). Néhány kontrollkísérletben nem tudták megismételni JUST és CARPENTER (1992) eredményeit, ezért hosszabb ideig tartó empirikus és a hipotéziseket érintő vita alakult ki a kapacitáselmélet körül. Magyar kísérletekben felnőtt mintán nem volt kapcsolat az olvasási terjedelem feladat és a mondatmegértés idői lefutása (önütemezett olvasási helyzetben) között. Ezzel szemben 10-12 éves gyerekeknél az olvasási terjedelem feladat jó bejóslója az önütemezett olvasási időknek (NÉMETH, m. a.). Összegezve az álláspontokat és kísérleti eredményeket az olvasási terjedelem feladatról (reading span) elmondható, hogy jól bejósolja az offline módszerekkel mért nyelvi teljesítményeket, de a megértés „gyors” on-line 
módszerekkel mért komponenseire nem ad magyarázatot. Elméleti szinten pedig a nyelvi teljesítmények egyéni különbségeivel kapcsolatban jobban megállja a helyét egy többkomponensű rendszer hipotézise.

\section{MUNKAMEMÓRIA ÉS IDEGRENDSZER}

A rövid távú emlékezet, illetve a munkamemória komponensei neuroanatómiai hátterének feltérképezésére számos módszer áll rendelkezésre. Ilyenek például a léziós állatkísérletek, a kognitív neuropszichológiai, az elektrofiziológiai vagy a hemodinamikai módszerek.

A munkamemóriát vizsgáló állatkísérletekben gyakran alkalmaznak késleltetett válasz teszteket (delayed-response tests), amely során az ingerprezentációt néhány másodperces szünet követi (késleltetés szakasza), majd az állatnak ki kell választania a helyes választ, például, hogy a kísérletvezető hova tette a táplálékot. Ezeknél a feladatoknál a prefrontális területek, valamint a parietális-prefrontális kapcsolatok játszanak jelentős szerepet. Primáta kísérletek eredményei alapján (GOLDMANRAKIC, 1987).

Az elektrofiziológiai módszerek, mint például az ERPs (event-related potentials) vagy az ERFs (event-related magnetic fields) előnyei: nagy idői felbontás, kényelmes kísérleti alkalmazhatóság, míg hátránya a gyenge téri felbontás.

A hemodinamikai módszerek megjelenésével az emlékezet agyi architektúrájának feltárása jelentősen felgyorsult. A modern agyi képalkotó eljárások (PET, fMRI) a helyi agyvéráramlást (rCBF) érzékelik, s így térképezik fel a relatív neurális aktivitást. E módszerek előnye a nagy téri felbontás, mely igen pontos lokalizációt tesz lehetővé. E szempont alapján az fMRI (functional magnetic resonance imaging) jelenleg megelőzi a PET-et (positron emission tomography). E módszerek gyengébb idői felbontásuk ellenére a kognitív idegtudomány egyik fő pillérét alkotják (a módszerekről jó áttekintést ad RUGG, 1999; valamint GULYÁs, 1999). A hemodinamikai módszerek eredményeinek interpretációját jelentősen segíti, illetve korlátok közé szorítja az agyi károsodásokból származó kognitív zavarok (például amnézia) elemzése (GABRIELI, POLDRACK, DESMONDO, 1998).

A teljesség igénye nélkül az alábbiakban összefoglalóan bemutatjuk a modern funkcionális képalkotó eljárások néhány eredményét a munkamemória-kutatás területén (CABEZA, NyBERG, 2000; SMITH, JONIDES, 1998 alapján).

A munkamemóriát többnyire prefrontális kérgi aktivitással szokták összekapcsolni. Fokozott aktivitás mutatható ki a Brodmann 6, 44, 9 és 46 területeken. A 44-es területen található aktivációnövekedés inkább verbális és numerikus feladatoknál mutatható ki, mint téri, illetve vizuális feladatoknál, és bal féltekei lateralizáció (Broca-terület) is megfigyelhető, ezért e területet (Br. 44) a fonológiai folyamatokkal, fonológiai feldolgozással kapcsolják össze. A 6-os terület mind verbális és téri feladatoknál, mind problémamegoldás során aktív, ezért ez általános, nem pedig anyag- vagy feladatspecifikus munkamemória-műveletekhez köthető. A 9 és 46-os területek az előbbiekkel szemben feladatspecifikusnak mondhatók: olyan műveletekhez köthetőek, melyek a munkamemória tartalmát manipulálják, 
mint például az „N-et vissza” (N-back) feladatnál; ugyanakkor nem mutatható ki relatív aktiváció ezeken a területeken (Br. 9,46), amikor tisztán az információ folyamatos fenntartásáról van szó, mint a késleltetett válasz feladatoknál. Az N-et vissza feladat a központi végrehajtó működésével kapcsolható össze.

A téri munkamemória-feladatoknál a dorzolaterális prefontális területek aktivációja a jellemző. A fonológiai hurok komponenseinek lokalizációja is eltér. A fonológiai tár a bal parietális, míg az artikulációs frissítés komponenshez bal prefrontális aktiváció, a 44-es terület (Broca) köthető. Azoknál a problémamegoldó feladatoknál - mint a London Torony vagy a WCST (Wisconsin Card Sorting Task) -, amelyeknél magas szintű munkamemória-működés jellemző, a 9/46-os terület mutat megnövekedett aktivációt. Mivel ezek téri hangsúlyú feladatok is, nem véletlen, hogy ezek a területek részben megegyeznek a téri munkamemória területeivel. A 10-es terület olyan magas szintű működésekre reflektál, mint a következtetés/tervezés, és ami külön figyelmet érdemel, hogy ez a terület összefügg a problémamegoldó feladatok epizodikus aspektusával.

A központi végrehajtóval kapcsolatban érdekes eredményt mutat be D’EsPOSITO (1995), aki azt találta, hogy két olyan feladat, amely külön-külön nem mutat prefrontális aktivitást, ha egyidejủleg, szimultán adjuk ezeket, akkor middorzális prefrontális aktivitás jellemző. A Stanford Egyetemen részben eltérő eredményre jutottak BUNGE és munkatársai (2000), akik egy időben és természetesen külön-külön is adtak a kísérleti személyeknek mondatolvasási, valamint rövid távú memóriafeladatot (utóbbiban 5 szót kellett rövid ideig tárolni). A kettős feladat helyzetben megnövekedett frontális kéreg aktivációt regisztráltak (fMRI), hasonlóan ahhoz, mint amikor a feladatokat külön-külön adták. De kettős feladathelyzetben a külön-külön helyzetekhez képest új prefrontális terület nem aktiválódott. A központi végrehajtó és a végrehajtó funkciók kutatása a kognitív idegtudomány divatos területe, ezért még számos eredmény várható, mely talán majd feloldja az ellentmondásokat.

Végezetül még egy megjegyzés. Újabb kutatások eredménye, hogy a kisagy kognitív folyamatokban (implicit tanulás, nyelv, emlékezet) betöltött szerepe egyáltalán nem elhanyagolható, és túlmutat az artikuláció motoros kontrollján. A verbális munkamemória működésében, szűkebben a fonológiai hurok frissítés komponensében is jelentős szerepe van (DESMOND, FIEZ, 1998). 

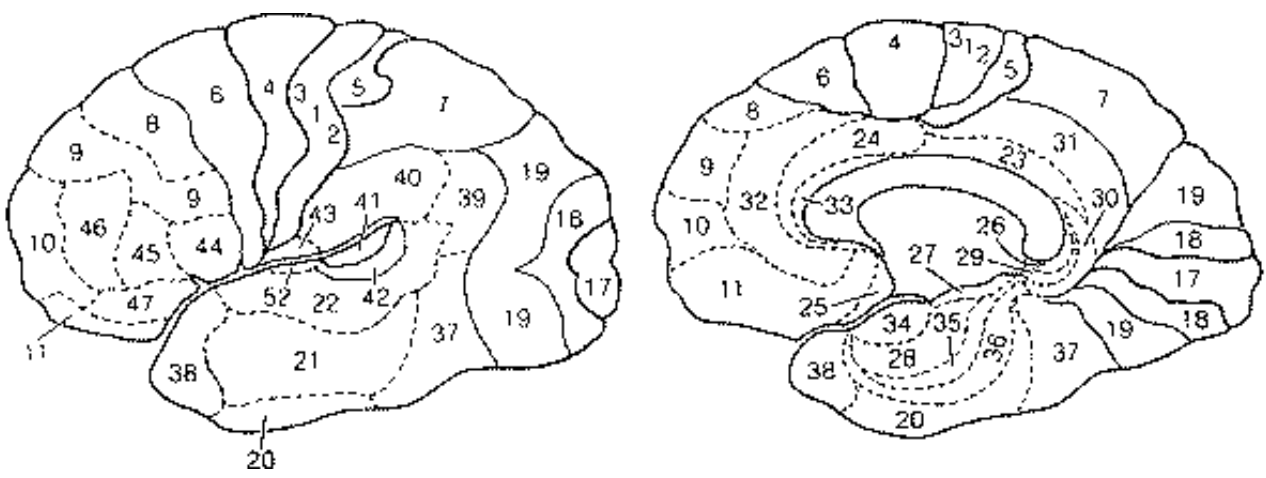

1. ábra. Az agy citoarchitektonikai régiói (BRODMANN szerint)

3. táblázat. A rövid távú memória és munkamemória neuroanatómiája modern agyi képalkotó eljárások (PET, fMRI) alapján (készült Gathercole, 1999, 412. Box 2. alapján)

\begin{tabular}{|c|l|l|l|}
\hline \multicolumn{3}{|c|}{ A MUNKAMEMÓRIA ÉS KÉRGI AKTIVITÁS } \\
\hline $\begin{array}{l}\text { Munkamemória (rövid } \\
\text { távú emlékezet) típusa }\end{array}$ & \multicolumn{1}{|c|}{ Kérgi területek } & Hemiszférium & $\begin{array}{c}\text { Brodmann- } \\
\text { terület }\end{array}$ \\
\hline $\begin{array}{c}\text { Fonológiai } \\
\text { tár (Storage) } \\
\text { artikulációs frissítés }\end{array}$ & poszterior parietális & Bal & 40 \\
(Rehearsal) & Broca-terület, & Bal & 44,6 \\
& premotoros kéreg, & Bal & 6 \\
\hline Téri & szuplementer motoros kéreg & Bal & \\
tár (Storage) & inferior prefrontális & Jobb & 47 \\
frissítés (Rehearsal) & posterior okcipitális, & Jobb & 19,40 \\
& premotoros kéreg & Jobb & 6 \\
\hline Végrehajtó funkciók & dorzolaterális prefrontális & Bal/ & $9,10,44$, \\
(executive processes) & kéreg & bilaterális & 45,46 \\
\hline
\end{tabular}

\section{KONKLÚZIÓ}

Tanulmányunkban igyekeztünk bemutatni, hogy a BADDELEY (2000) nevéhez füződő többkomponensủ munkamemória-elmélet jó szemléleti és interpretációs keretet nyújt nemcsak a kognitív pszichológia, hanem a neuropszichológia, valamint a kognitív idegtudomány számára is. A nemszóismétlési-teszt érzékeny mérőeljárása a fonológiai hurok kapacitásnak, és jó bejóslója a nyelvtanulási képességnek mind az első, mind a második nyelven. Olyan nyelvi károsodások esetén, mint az SLI vagy a dyslexia, diagnoszikai jelentősége lehet. Az olvasási terjedelem fel- 
adat - jóllehet nem tisztázott, hogy a feladat milyen komponensek működését igényli - jól használható mérőeszköze az aktív rövid távú memóriának, és jó bejóslója a szövegmegértési és mondatértelmezési képességnek. A munkamemóriaalrendszerekkel kapcsolatos kiterjedt kognitív idegtudományi kutatás napjainkban lehetőséget teremt arra, hogy a kísérleti laboratóriumokban megalkotott elméleti modell hasznossá váljon az idegrendszeri sérülések térképezésénél és rehabilitációjánál.

\section{IRODALOM}

Atkinson, R. C., Shittrin, R. M. (1968) Human memory: a proposed system and its control processes. In Spence, K. W., Spence, J. T. (eds) The psychology of learning and motivation: Advances in research and theory. Vol. 2, 89-195. Academic Press, New York

BAdDeley, A. D. (1998) The central executive: A concept and some misconceptions. Journal of the International Neuropsychological Society, 1998 Sep; Vol 4 (5) 523-526.

Baddeley, A. D. (2000) Az emberi emlékezet. Osiris Kiadó, Budapest

Baddeley, A. D., Gathercole, S. D., Papagno, C. (1998) The phonological loop as a language learning device. Psychological Review, 105, 158-173.

Baddeley, A. D., Hitch, G. J. (1974) Working memory. In Bower, G. H. (ed.) The psychology of learning and motivation: Advences in research and theory. Vol. 8, 47-89. Academic Press, New York

Baddeley, A. D., Logie, R. H. (1999) Working memory: The multiple-component model. In Miyake, A., Shah P. (eds) Models of working memory. Cambridge University Press, Cambridge

Bunge, S. A., Klinberg, T., Jacobsen, R. B., Gabrieli, J. D. E. (2000) A resource model of the neural basis of executive working memory. Proc. Natl. Acad. Sci, Vol. 97. 3573-3578.

CabezA, R., Nyberg, L. (2000) Imaging Cognition II: An Empirical Review of 275 PET and fMRI Studies. Journal of Cognitive Neuroscience, Vol. 12, Number 1, 1-47.

Caplan, D., Waters, G. S. (1999) Verbal working memory and sentence comprehension. Behavioral and Brain Sciences, 22, 77-126.

Carpenter, P. A., Miyake, A., Just, M. A. (1994) Working memory constraints in comprehension. In Gernsbacher, M. A. (ed.) Handbook of psycholinguistic. Academic Press, INC. San Diego, California, 1075-1122.

Czigler I. (1988) A Ranschburg-effektus. Pszichológia, 8, 279-296.

D’Esposito, M., Detre, J. A., Alsop, D. C., Shin, R. K. (1995) The neural basis of the central executive system of working memory. Nature, 378 (6554), 279-281.

DAMÓ E. (2000) Szakdolgozat. ELTE, BTK, Pszichológia szak. Kézirat

Daneman, M., CARPenter, P. A. (1980) Individual differences in working memory and reading. Journal of Verbal Learning Verbal Behavior, 19, 450-466.

Desmond, J. E., Fiez, J. A. (1998) Neuroimaging studies of the cerebellum: language, learning and memory. Trends in Cognitive Sciences, Vol. 2, No. 9, 355-362.

Ellis, N. C., Hennelley, R. A. (1980) A bilingual word-lenght effect: Implications for intelligence testing and the relative ease of mental calculation in Welsh and English. British Journal of Psychology, 71, 43-52. 
Gabrieli, J. D. E., Poldrack, R. A., Desmondo, J. E. (1998) The role of left prefrontal cortex in language and memory. Proc. Natl. Acad. Sci, Vol. 95. 906-913.

Gathercole, S. E. (1999) Cognitive approaches to the development of short-term memory. Trends in Cognitive Sciences, Vol. 3, No. 11, 410-419.

Gathercole, S. E., Hitch, G. J. (1993) Developmental changes in short-term memory: a revised working memory perspective. In Collins, A. F., Gathercole, S. E., Conway, M. A., Morris, P. E. (eds) Theories of Memory. Lawrence Erlbaum, Hove 189-211.

Gathercole, Susan-E.; Willis, Catherine-S.; Baddeley, Alan D., Emslie, Hazel (1994) The Children's Test of Nonword Repetition: A test of phonological working memory. Memory (Special Issue: Memory tests and techniques) 1994 Jun; Vol 2 (2) 103-127.

Goldman-Rakic, P. S. (1987) Circuitry of primate prefrontal cortex and regulation of behavior by representational memory. In Plum, F. (ed.) Handbook of Physiology - The Nervous System V. Oxford University Press, New York, 373-417.

Gulyás B. (1999) A PET az ezredfordulón. Magyar Tudomány, XLIV., különszám

Johnisse, M. F., Seidenberg, M. S. (1998) Specific language impairment: a deficit in grammar or processing. Trends in Cognitive Sciences, Vol. 2. No. 7, 240-247.

Just, Marcel Adam, Carpenter, Patricia A. (1992) A capacity theory of comprehension: Individual differences in working memory. Psychological Review, 1992, Vol. 99. No. 1, $122-149$.

Just, Marcel Adam, Carpenter, Patricia A. (1996) The Capacity Theory of Comprehension: New Frontiers of Evidence and Arguments. Psychological Review, 1996, vol. 103, No. 4, 773-780.

Karmiloff-Smith, A. (1998) Development itself is the key to understanding developmental disorders. Trends in Cognitive Sciences, Vol. 2. No. 10, 389-398.

Murdock, B. B. JR. (1974) Human memory: Theory and data. Erlbaum, Hillsdale

Németh D. (megjelenés alatt) A munkamemória szerepe a mondatmegértésben. In Pléh Cs., Lukács Á. (szerk.) Morfológiai feldolgozás a magyar nyelvben. Osiris Kiadó, Budapest

PARKIN, A. J. (1998) The central executive does not exist. Journal-of-the-InternationalNeuropsychological-Society. 1998 Sep; Vol 4 (5) 519-525.

PInker, S. (1999) A nyelvi ösztön. Typotex Kiadó, Budapest

RACSMÁny M. (2000) A munkamemória szerepe a megismerésben. Erdélyi Pszichológiai Szemle, Megjelenés alatt

RAnschubrg P. (1902) Über Hemmung gleichzeitiger Reizwirkungen. Zeitschrift für Psychologie, 30, 39-86.

RUGG, M. D. (1999) Functional neuroimaging in cognitive neuroscience. In Brown, C. M., Hagoort, P. (eds) The Neurocognition of Language, Oxford University Press, New York, $15-36$.

SERvice, E. (1992) Phonology, working memory, and foreign -language learning. Quarterly Journal of Experimental Psychology, 45A, 21-50.

Smith, E. E., Jonides, J. (1998) Neuroimaging analyses of human working memory. Proc. Natl. Acad. Sci, Vol. 95. 12061-12068.

WATERS, G. S., CaPlan, D. (1996) The capacity theory of sentence comprehension: critique of Just and Carpenter (1992). Psychological Review, 1996, vol. 103, No. 4, 761-772. 


\title{
WORKING MEMORY CAPACITY TASKS AND THEIR ROLE IN NEUROPSYCHOLOGICAL DIAGNOSIS
}

\author{
NÉMETH, DEZSŐ-RACSMÁNY, MIHÁLY-KÓNYA, ANIKÓ-PLÉH, CSABA
}

This study reviews various working memory tasks used for neuropsychological assessment. Since the possible cause of many language and memory disorders could be the injury of one of the working memory subsystems, working memory tasks are crucially important in diagnosing short-term memory problems. The authors present the detailed analysis of the Hungarian version of Daneman and Carpenter's reading span task and the Hungarian version of the phonologocial non-word repetition test. These tests can be of good use in diagnosing Specific Language Impairment and other language disorders. The authors intend to outline the possible relationship between working memory subsystems and neuropsychological tests, some validity problems and present recent results of working memory research.

Key words: $\quad$ working memory capacity, language acquisition, brain localization, neuropsychological diagnosis 